\title{
TEKST OG BILLEDE I ETNOGRAFISK FORMIDLING
}

\author{
Mytte Fentz
}

Både etnografien og de etnografiske billeder forsøger på kreative måder at udforske livets virkelighed. Men da vi kun opfatter dele af den virkelighed der omgiver os, og tilmed iser opfatter den visuelt, så kan billedlige indtryk, fastholdt fotografisk på rette måde og på rette tidspunkt, fortalle langt mere end mange ord.

\section{DEN VISUELLE TILFØJELSE}

Moesgård Museums etnografiske udstilling 'Bjergfolk i Hindu Kush', baseret på danske ekspeditioner i 1940 'erne og 50 'erne blev i 1994, i forbindelse med FN's familieår, udbygget med et aktuelt billedessay om Kalasha-folket i Hindu Kush-bjergene i NV Pakistan. Med billedfortællingen er der skabt en forståelse mellem det historiske og aktuelle bjergfolk samt en dialog mellem fortid og nutid i Moesgård Museums scenisk arrangerede tableauer.

Men at indfange dramaet i Kalasha-folkets historisk og kulturelt bestemte dagligdag indebærer samtidig indtrængen og forstyrrelse. Under denne nøgterne proces er det netop at etnograf og billedmager må arbejde på samme måde for at etablere kendskab og tæt relation til de lokale folk. $\mathrm{Da}$ vi langtfra er anonyme, påvirker vi situationen og oplever samtidig en skærpelse af vor egen tilstedeværelse ved at dykke ned $i$ en anden virkelighed for at fange stumper af denne, som ingen af os kender dybden eller omfanget af. Vi bevidstgør os selv og den anden part, lokalsamfundets aktører. Dette kunne kaldes iscenesættelse! Men alt samvær er jo en form for iscenesættelse, som viser tilbage til denne bevidstliggørelse. Men for os som skriver teksten, som tager billederne, forbliver det et vanskeligt spørgsmål hvorledes vi skal reducere distancen mellem betragteren og det betragtede, en proces som Crawford og Turton (1992) beskriver som en konstant vekslen imellem nærvær og fravær, for at distancere sig under en følgende analytisk proces. Lokalsamfundet bliver aktører i etnografens og billedmagerens endelige resultater der måske rækker så vidt at det lykkes at indfange ny viden som overrasker.

Ved at udbygge den eksisterende genstands- og tekst-udstilling med en billedfortælling om Kalasha samfundets aktuelle dagligdag formidles samtidig en dialog imellem to ligeværdige aspekter, de historiske genstande, som del af rekonstruerede 
70 miljøer, og nutiden. De to statiske udsagn, fortid og nutid, spejler sig gensidigt, anskueliggør forandringsprocesser, især indenfor den materielle kultur, og bibringer hermed den besøgende en mere perspektivrig oplevelse af det pågældende samfund.

Billeder såvel af ældre som af nyere dato formidler en lang række budskaber til museumsgæesten, som langt mere umiddelbart kan indleve sig i den fremmede kultur og samtidig gennem billedet iagttage brugen af den materielle kultur og dermed følge dele af samfundets hverdagsrytmer. Saledes kan billedet, ifølge Umberto Eco, ligefrem skabe en synergi mellem det visuelle og det skrevne. Han mener at en gængs reaktion på billedmediet ligefrem ansporer til en øget nysgerrighed og interesse for det trykte ord. Så med få ord som ledsagende tekst kan såvel det historiske som det aktuelle billede tjene som en langt bedre orientering om geografiske som topografiske forhold, om lokale agerbrugssystemer, samt landsbyers beliggenhed og indre struktur. Men billedfortællingen kan også indfange adfærdsformer offentligt og privat.

\section{SAMFUNDET}

'Kalasha Kafirerne', de 'Vantro Kalash', som de omkringboende muslimer ynder at kalde denne minoritet under republikken Pakistan, er bosat i tre bjergdale sydvest for Chitral by. Her lever Kalashafolket, et indoeuropæisk folk på omkring 3000 ialt, fortsat efter traditioner, der er uløseligt sammenbundet med deres religion, som kan relateres til en hinduistisk præget oldform.

Religionen rummer et tilsyneladende entydigt sæt leveregler, som Kalasha'erne fortæller er grundlæggende for deres samfunds indre struktur og dagligdag hvor mand og kvinde har hver sit arbejdsområde. Denne kønsbaserede arbejdsdeling er religiøst og traditionelt betinget og indeholder også en symbolsk adskillelse mand og kvinde imellem. Dette betyder ikke, at de to køn har 'ulige' værdier, men at begge har magt og indflydelse indenfor deres respektive virkefelter og samtidig indgår som komplementære led i produktionen. Fysisk er det mandlige samtidig knyttet til 'oppe' eller 'borte' fra landsbyens centrum, hvorimod kvindens aktiviteter foregår 'nede' i dalen eller 'tæt på' det sociale centrum.

Sæterdriften med geder, som passes af mændene og drengene er onjesta, religiøst rent, hvorimod agerbruget på kunstvandede marker i dalene, passet af kvinderne og de unge piger, er praghata, religiøst urent. Både naturen og boligen har usynlige, men for Kalasha-folket kendte grænser, der adskiller rituelt rene områder fra urene. Mændene må ikke nærme sig områder der er praghata, og de har således ingen adgang til Bashali'en, kvindehuset, hvor kvinderne opholder sig under menstruation og børnefødsler, beskyttet af gudinden Dezalik. Modsat må kvinderne ikke vandre med til den øverste del af sæteren, som er onjesta, eller komme nær helligstederne for Mahandeo eller Sajigor, områder som ligger udenfor og ovenover landsbyen og som kun må betrædes af drenge og mænd. I slægtshelligdommen Jestakhan'en, i landsbyens centrum, kommer derimod alle familiemedlemmer.

Flytter vi imidlertid opmærksomheden fra denne officielle præsentation af Kalasha samfundet, efter hvilken alle måt- 


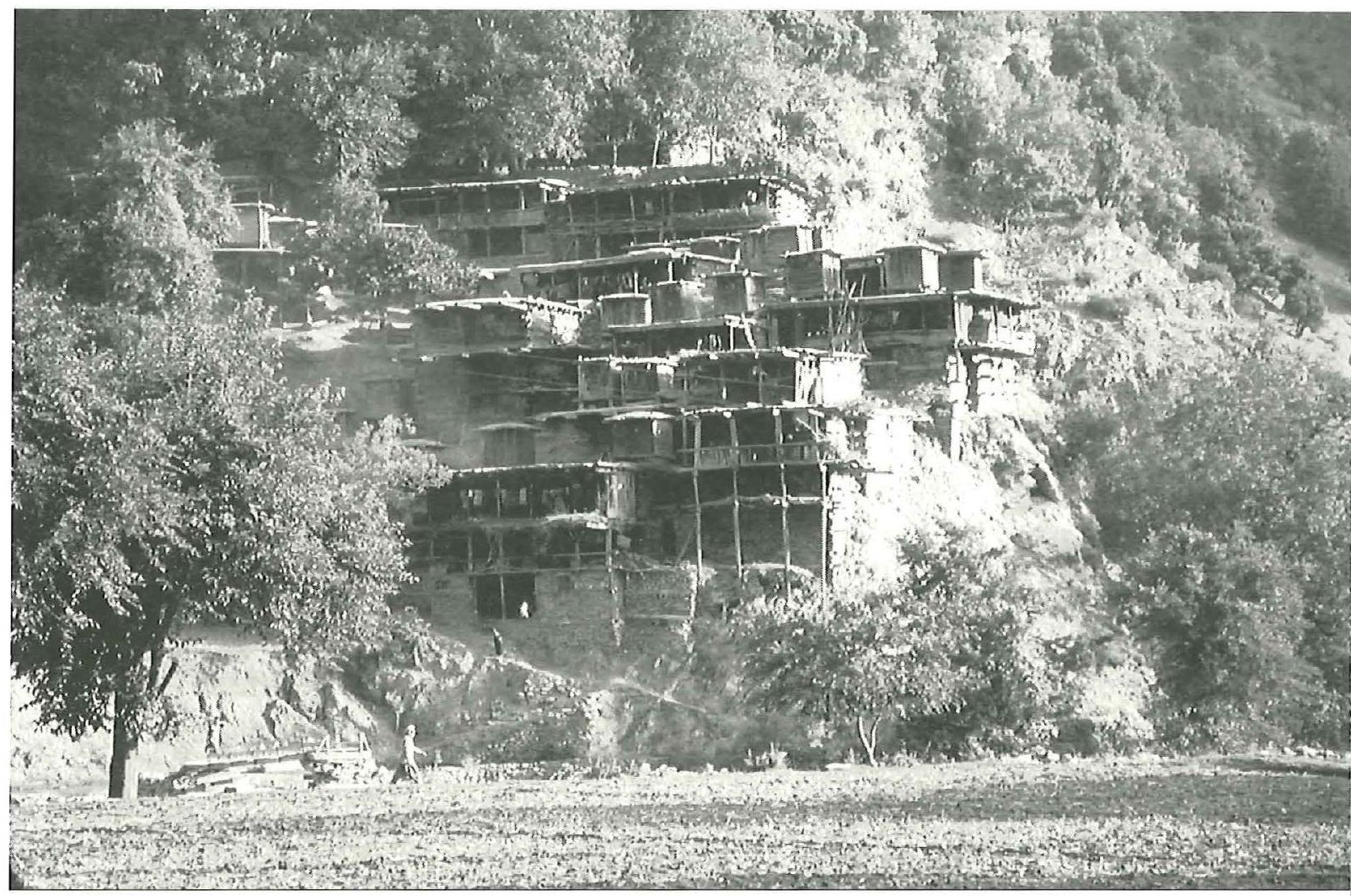

I det vildsomme Hindu Kush klynger landsbyerne sig til de stejle og golde klippesider for ikke at optage den sparsomme agerjord $i$ dalbunden. Af cedertre, sten og stratiliblandet jord har lokalbefolkningen skabt starke, men eftergivelige huse som derfor ubesvaret modstår de hyppige jordrystelser som er karakteristisk for disse egne. Husene er stablet ovenpå hinanden, eller bygget i forskudte niveauer og indbyrdes forbundet med trappelob udhugget af trestammer. Alle fotos: M. Fentz \& T. Stroyer.

te leve harmonisk efter de samme værdier og reagere ens i forskellige sammenhænge, til den mere praktiske hverdag, så viser det sig, at disse religiøse værdibegreber individuelt administreres helt anderledes nuanceret. Hos én familie, som udadtil fremstod som idealet på denne mikrostruktur, konverterede forældrene for henved tredive år siden til Islam under hårdt pres fra Chitrali-muslimer. Da den øvrige familie på omkring 25 medlemmer fortsat er Kalasha, praktiseres begge religioner indenfor den samme familiestruktur. Asymmetrien mellem det 'officielle Kalasha samfund' og denne familie er således et godt eksempel på hvordan det enkelte individ reagerer på forskellige situationer og handler udfra egne erfaringer. I de officielle værdibegreber har familien således indpasset helt andre sæt af praksisregler som del af hverdagen.

\section{SKRIFT OG BILLEDE}

Det er gennem studiet af samfundsstrukturer og social aktivitet vi erfarer verdens indretning og sammenhæng. I dag, hvor mennesker, varer og informationer bevæger sig på tværs af alle grænser, ændrer samfund sig langt hastigere end før. $\mathrm{Og}$ derfor bliver det etnografiske museums opgave, blandt mange andre, at skabe øget viden og forståelse for mennesker med en anden kulturel baggrund. Samtidigt er det i langt højere grad blevet væsentligt ikke alene at registrere de traditionelle kulturer, men også at søge at forstå vekselvirkningen mellem disse og omverdenen og at videregive denne viden.

Moesgård Museums permanente udstilling Bjergfolk i Hindu Kush har fået en fornyet aktualitet med den store bevågenhed, som etniske og nationale minoriteter er genstand for $\mathrm{i}$ dag. Denne udstilling er 


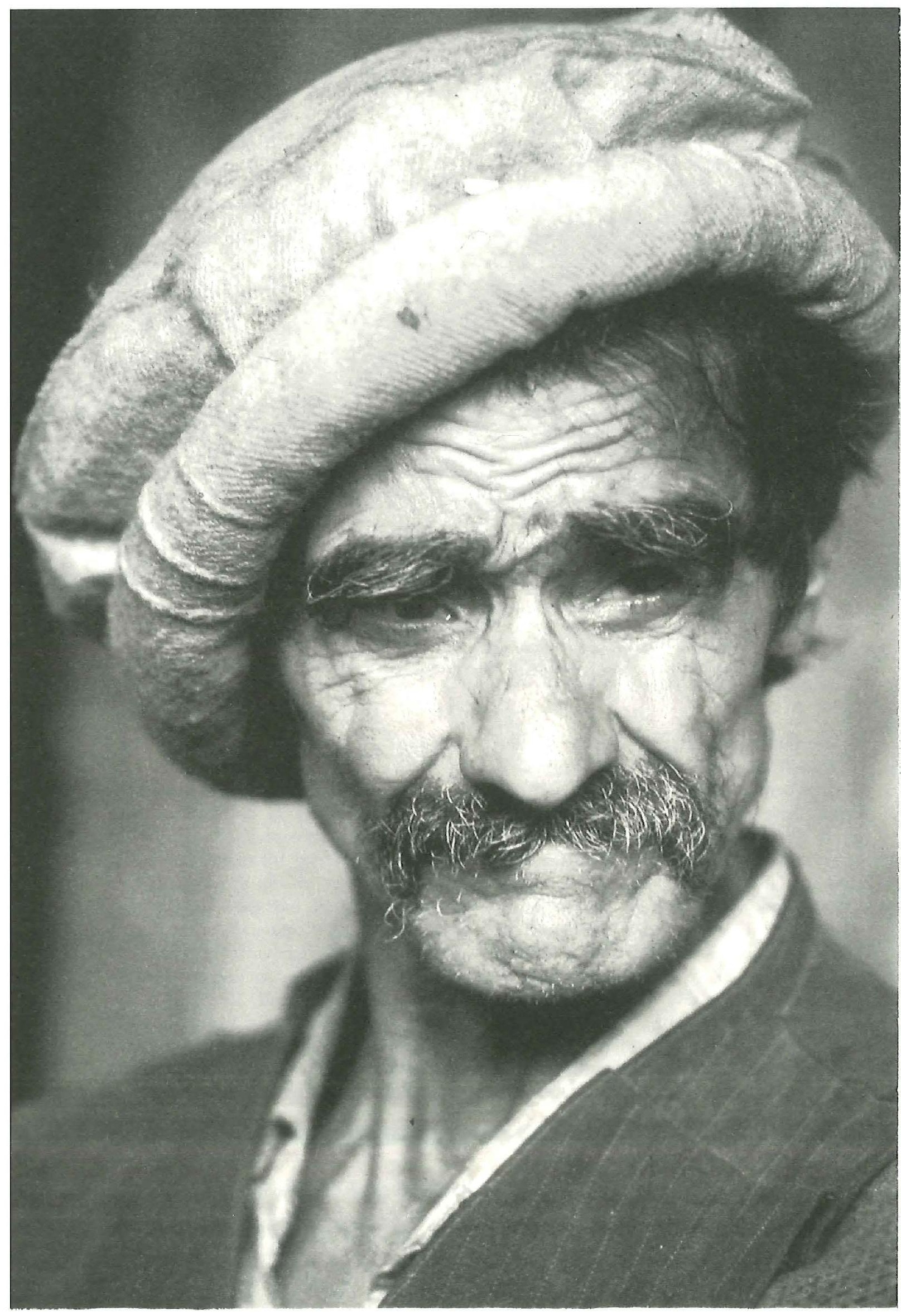


opbygget, så den ikke kun isolerer en kort periode af bjergfolkets historie. Den forklarer også hvad der er gået forud, men uden egentlig at engagere sig i samfundenes aktuelle nutid. Nok rummer udstillingen genstande både fra en historisk tid og fra idag, men udstillingsmiljøet overlader, som nævnt, ved sin tableaubaserede opbygning den besøgende til en række fastfrosne skildringer af et nulevende folk og dets historie, en præsentation, som signalerer en entydig opfattelse af samfundets virkelighed, og som også undlader at inddrage museumsgxsten i den kompleksitet, som samfundets forandringsprocesser og aktuelle problemer rummer. Kalasha samfundet, en af de mindste minoriteter i forbundsrepublikken Pakistan, kæmper for sin etnicitet i en dagligdag, der er præget af et nærmest antitetisk kulturelt forhold til de fra hovedbyen Chitral Town tilflyttede muslimer. Den permanente udstillings budskab signalerer snarere en minoritet, der lever i et 'ideologisk reservat', og i ligeså høj grad viser udstillingen den kulturopfattelse, at Verden består af homogene kulturelle enheder. Ved brug af rekonstruerede udsnit af miljøer formår Moesgård Museums udstillings budskab ikke at formidle det virkelige livs langt større kompleksitet.

Antropologisk set er fotografiet et nyere objekt og som informationskilde ikke accepteret af alle på lige fod med tekstens semantiske evner. Disse potentielle forskelle mellem det tekstuelle og det visuelle diskuteres og defineres af Kirsten Hastrup (1992), men uden den overvejelse, at de menneskelige sanser interkommunikerer, så det sete bliver tekstuelt og det tekstuelle omskabt til billedlige erindringer. Det virker formålsløst at ville fastholde en skarp uforenelighed mellem 'ord' og 'billede' som Hastrup argumenterer for, da ingen af disse værdier kan eksistere som rendyrkede fænomener. Tanker er baseret på de menneskelige sanser, som udgør en kompleksitet, og som for forståelsen er indbyrdes afhængige af hinanden, da man opfatter holistisk. Således nægter Umberto Eco ligefrem at vedkende sig den holdning 'at skrift er godt og billeder er dårlige, at det ene er kultur og det andet tomhed'. 'Fotografiet opfanger og udleverer øjeblikkeligt alle de detaljer det har indfanget - i modsætning til teksten, der ved et enkelt ords pludselige virkning kan få sætningen til at skifte fra beskrivelse til reflektion'.

Krass Clement udbygger disse argumenter og siger at fotografiet ikke kun er det, der ikke er mere, men også, og med garanti det, der har været. Fotografiets essens er at stadfæste det, som det forestiller. Denne vished kan derimod intet skriftligt vidnesbyrd videregive til os. Det er nok sprogets ulykke ikke at kunne gøre sig autentisk i forhold til det, det vil beskrive. Fotografiet derimod er uanfægtet af enhver form for

Kasi'en er Kalashafolkets historie i een mand. I et skriftlost samfund som Kalasha, er Kasien, landsbyens traditionsvogter, en sardeles vigtig person. Han holder styr på ritualer og alle vigtige sporgsmål, der angår samfundet som slagtskabsrelationer, giftermail, ejendomsret til jord, treer og gresgange i dalen og på sateren. Kasien baserer sin viden på arveforhold og de traditionelle uskrevne love. Han er også mester $i$ at erindre legender, som beretter om Kalashasamfundets historie og kulturelle arv. Skont samfundets 'love' er uskrevne, sä è der normer, som tillader folk at have forventninger til andres adfard. Efterleves disse uskrevne love ikke, samles landsbyraidet af aldre mand for at afgore stridighederne. 
Mytte Fentz

74 mellemregning: det opdigter ikke, det er godkendelsen i sig selv tilføjer Barthes (1983). Ethvert fotografi er således et tilstedeværelsesbevis. Hastrup argumenterer (1992), at antropologen, udstyret med notesbog eller kamera, altid vil definere virkeligheden $\mathrm{i}$ det øjeblik han opdager den. Men herimod kan indvendes, at på dette tidspunkt ville det allerede være for sent for fotografen at tage billedet. Så mit modargument er, at etnografen undertiden 'står i vejen for sig selv', rent professionelt. Men et lykkeligt samarbejde mellem etnograf og fotograf kan måske netop løse dette problem såvel forsknings- som formidlingsmæssigt.

\section{BILLEDETS STYRKE}

Skal antropologen opnå et resultat, som kan blive til andet og mere end blot fortælling, må der anlægges en objektiv indstilling til det levede liv som omgiver ham. Denne objektivering kan imidlertid kun finde sted på baggrund af en subjektiv indlevelse og forståelse. Skønt denne sansning af den ikke-sproglige sociale og praktiske viden i dag indrømmes en langt større plads i den antropologiske erkendelse (Hastrup \& Hervik 1994), hvordan kommer vi så fra den sociale erfaring og umiddelbare forståelse af andres liv til den videnskabelige objektivering og præsentation? Hvorledes kan indtryk og oplevelser fastholdes, udbygges og raffineres?

Billedets styrke er dets tilknytning til virkeligheden, men samtidig er det også dets svaghed. Søger det at indfange og fastholde livet eller virkeligheden, når vi uhjælpeligt frem til en modsigelse, da livet er en abstrakt størrelse. Men også 'virkeligheden' har flere lag. Og man kan lige- frem blive tvunget til at gå forbi det tilsyneladende virkelige for at indfange det egentlige eller virkelige. Spidsfindigt eller ej, men er det ikke netop her udfordringen til billedmageren ligger? Fotografen Krass Clement beskriver denne udfordring som 'en nødvendig søgen indad i sig selv i forsøg på at skabe en overensstemmelse med omverdenen', samt nødvendigheden af 'at fotografere mere end den tilsyneladende virkelighed ved at være til stede, ved at se, ved at leve med for at fange dagliglivets rytme og drama på filmstrimlen'. Alligevel må det erkendes at en subjektiv iscenesættelse hindrer os $\mathrm{i}$ at indfange den evigt undvigende sandhed. Så spørgsmålet er, om det er samfundets skjulte eller afdækkede virkelighed vi endeligt præsenterer?

Det er imidlertid en kendsgerning, at den fotografiske praksis og det færdige produkt altid vil være et resultat af den kulturhistoriske proces, vi er en del af. Der findes altså forskellige 'synsvinkler' at indfange den samme omverden på. $\mathrm{Og}$ 'bvis ojnene selv tanker', som Cézanne udtrykker det, så bør vi overveje muligheden af kulturelt forskellige blikke. Blikket er ganske enkelt noget man lærer, og resultatet er kulturspecifikke blikke som igen må kunne aflæses af fotografers forskellige resultater. Spørgsmålet bliver dernæst hvis fotografiske gengivelse, der er den mest sande?

Hvis den fysiske verden, der omgiver os, ikke er verden selv, men et kulturelt modificeret billede af den, er der vel nxppe nogen stor perceptiv forskel på at se den fysiske verden og dens billedlige repræsentation. En ambivalent holdning hos visse antropologer til billedgengivelsens værdi er derfor helt naturlig. Da vi netop ind- 


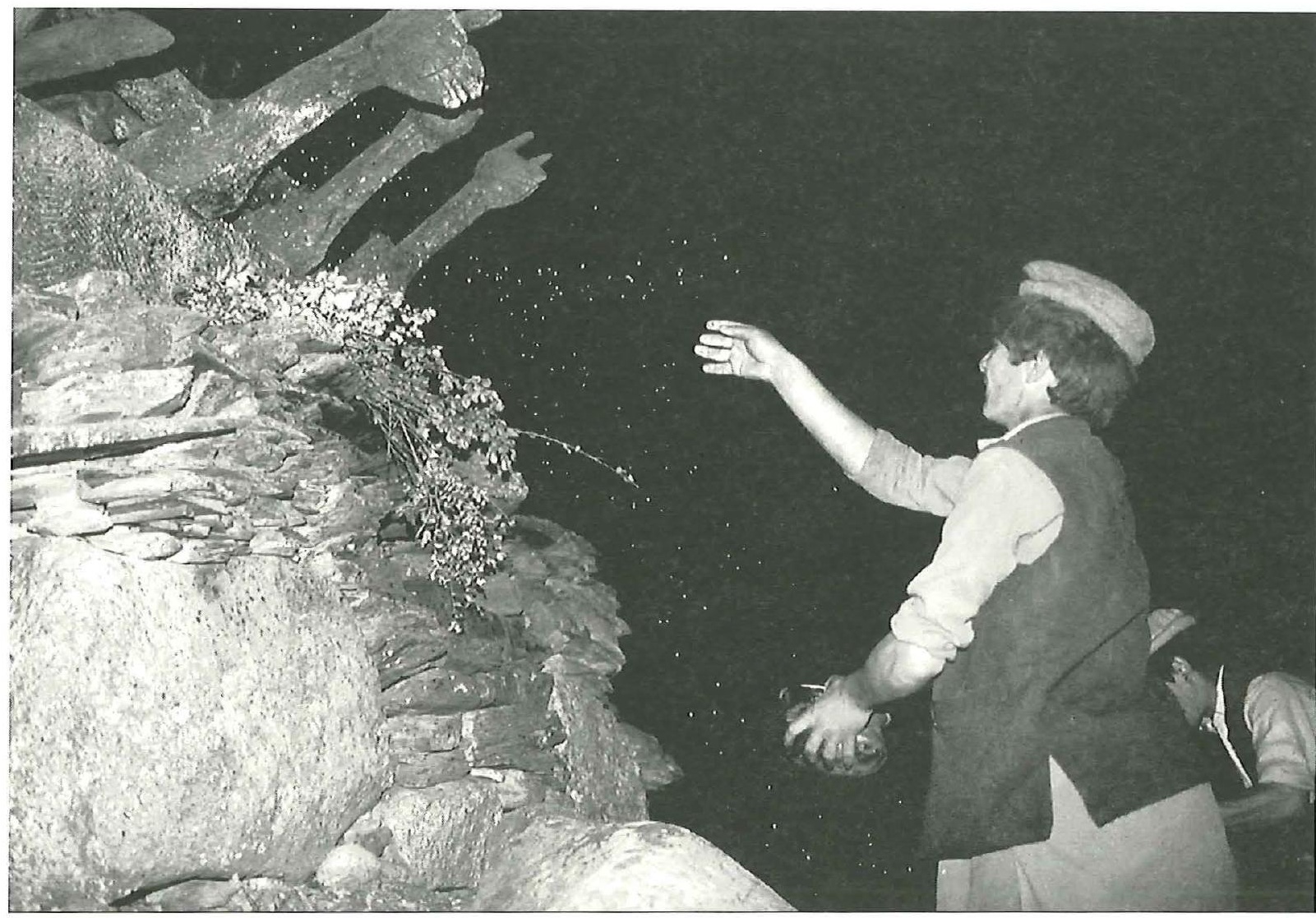

Gudernes gunst sikres ved religiose ceremonier. Der ofres gedekid, mel, malk og ost ved helligstederne. Dramaet under disse offerhandlinger lader sig vanskeligt forklare, men symboler som gedekiddets blod, malken, brodet, ilden samt antandte enebargrene indgair i det rituelle forlob. Rogen symboliserer kontakten med guderne. Helligstedet Mahandeo dûr markeres af hestehoveder festet på toppen af en gigantisk klippeblok.

vinder viden ved at se og høre den fysiske verden omkring os, observerer dét der eksisterer, i overensstemmelse med en positivistisk angrebsvinkel. Den fotografiske gengivelse kan imidlertid forekomme lige så lødig og visuelt virkelig som den fysiske verden, den repræsenterer, og samtidigt er den, ligesom det tekstuelle, dog kun repræsentationer af den. Men billederne aftegner reelt eksisterende mennesker og deres aktuelle materielle kultur, da aktørerne på billederne ikke kan tørre sminken af og bagefter gå hjem til en anden virkelighed efter optagelserne.

\section{DEN NYE VIRKELIGHED OG LOYALITETEN}

Som feltnoterne efter et forskningsophold gennemgår en redigering til etnografiske tekster, der i teoretiserende og sandhedssø- gende analyser forsøger at forklare andre samfund, vil tilsvarende ske med det fotografiske materiale. Fragmenter af en virkelighed bliver efterfølgende bearbejdet udfra valg af motiv, billedteknik samt belysning hvilket også automatisk resulterer $\mathrm{i}$ en tolkning af det liv og den verden de fotograferede folk lever i. Resultatet udgør nu et samlet nyt univers, som med et beskrivende udtryk da også bliver kaldt en 'æstetisk flertydighed' (Crawford \& Simonsen 1992). Skønt redigeringen af forskningsmaterialet foregår med finfølelse og resultatet fremtræder som en metafor for etnisk selvfølelse i den endelige rapport, er vore publicerede produkter alle resultater af sociale og kulturelle processer, som kontakten mellem antropologen og en bestemt gruppe mennesker igangsætter. Elementer af en virkelighed, som allerede er fortid, når fotografiet er taget, stykkes 


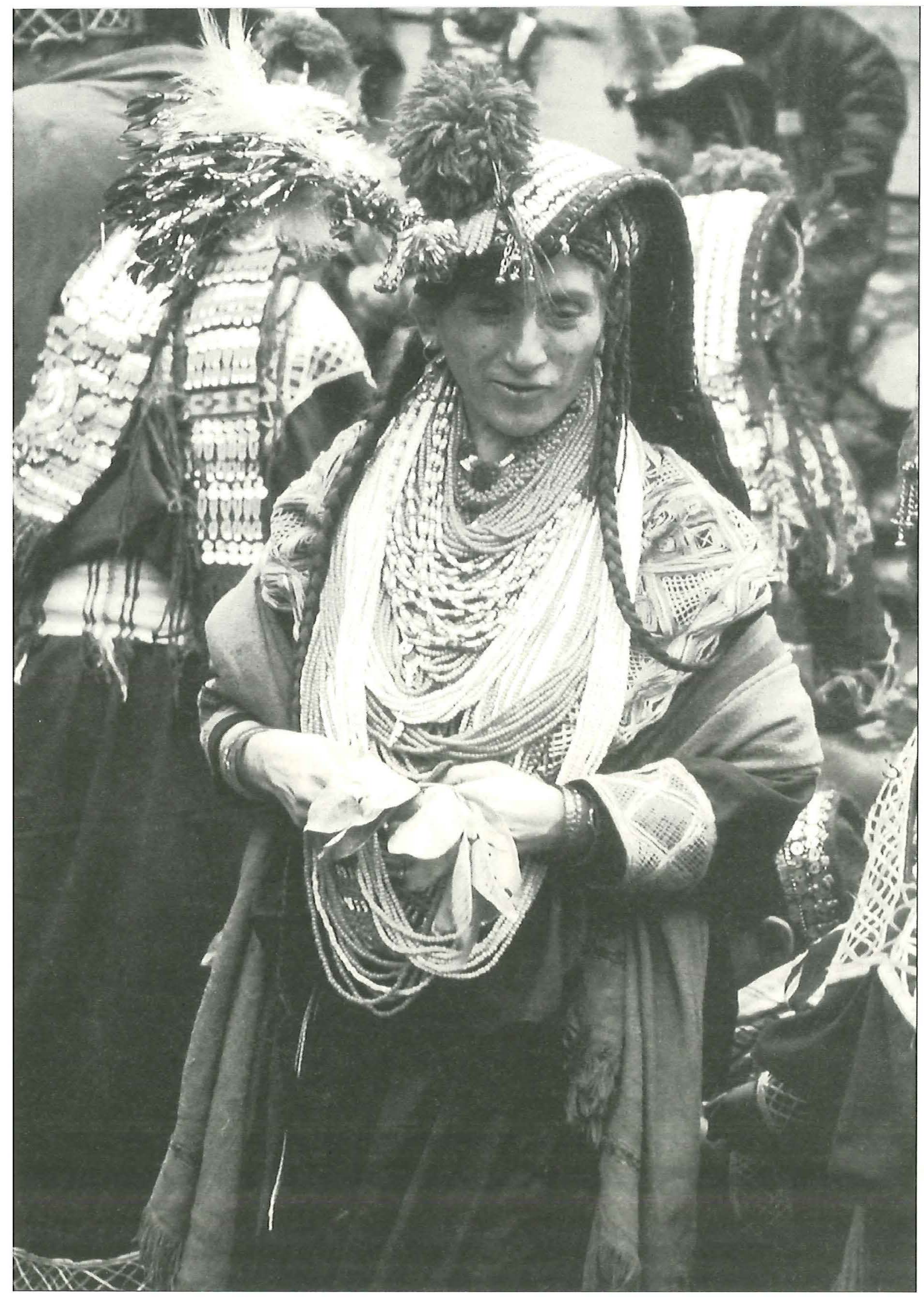




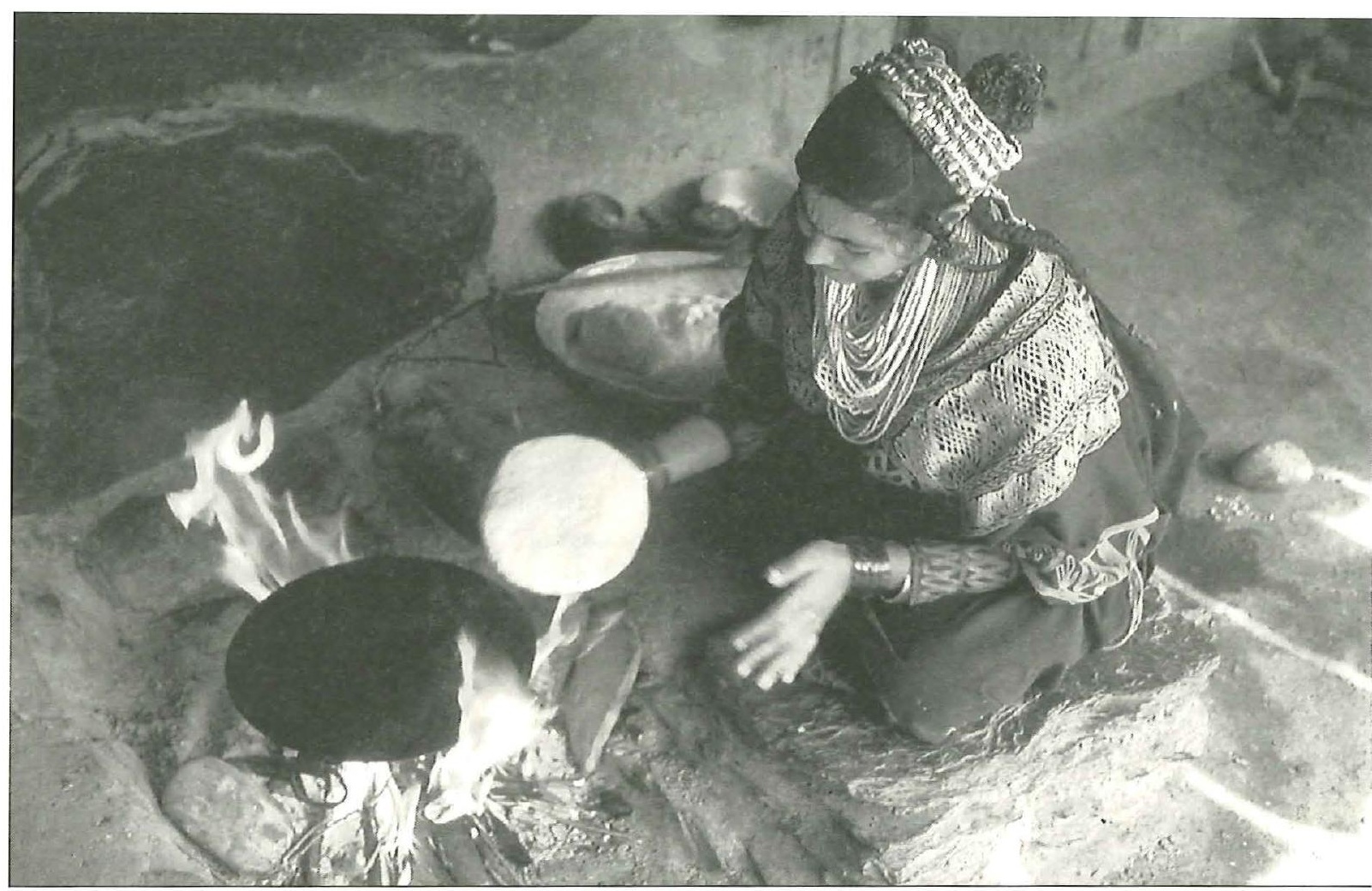

Over: Brod er en af Kalasha'ernes vigtigste naringsmidler og bages derfor flere gange i dagens lob. Kvinden maler selv sin majs-eller hvedemel $i$ en af de mange lokaltejede vandmoller.

Til venstre: Kvinden barer den traditionelle fodlange, sorte Kalashadragt. Halsen tynges af overdadige mangder af perlekeder i rode og hvide farver. På toppen af glasperlerne hviler en kraftig spiralsnoet solvring, en saikaldt torque, prydet med ciseleringer og indlagte flussten. Halsringen tilkendegiver at kvinden er gift og den har samme hoje vardi som en ko. Om det morke harpiksglinsende hår, der er samlet i fletninger, barer kvinderne et baind, en chuchut, samt en kupas, det traditionelle Kalashahovedtoj prydet med rode glasperler, messingklokker og cowriskaller fra Det indiske Ocean. En så pompos udsmykning vakker naturligvis opmarksombed og beundring. Men da kvinden i langt hojere grad end manden er symbol på etnisk identitet og synliggorelse af den traditionelle Kalasha kultur, representerer hendes udsmykning samtidig et komplekst system af sociale fanomener, prestige og personlig kommunikation.

sammen og opstår på surrealistisk vis som en ny virkelighed. Eller med Crawfords ord: 'At tage billeder er ligesom antropologi, en skabende udforskning af virkeligheden under udvælgelse' (Crawford 1992). At anerkende og respektere 'den stedlige kilde' som medforfatter betyder samtidigt at respektere og inddrage ham/hende i denne ny virkelighed og i den endelige tekst. Lyttes der til 'den lokale stemme' på lige fod med etnografens vil billedessayet i social og materiel sammenhæng glide ind som en metafor $\mathrm{i}$ et samspil med den lokale legende, som et supplement til den etniske bevidstliggørelse og selvforståelse.

Skønt dét der foregik igår, ikke nødvendigvis er mere interessant eller vigtigere end det, der vil foregå imorgen, så er det dog liv, siger Krass Clement. Det er liv som det blev levet før og som det vil fortsætte med at blive levet efter billedoptagelserne. Derfor vil den information, som kan erhverves udfra både ældre og nyere fotomateriale til at underbygge, dokumentere og checke etnografiske statements, samtidig have en betydelig videnskabelig værdi. Det er således min konklusion, at fotografiet $i$ en etnografisk og socialantropologisk sammenhæng kan anvendes til andet og mere end blot registrering $\mathrm{i}$ en fortsat skabende udforskning af den sociale og materielle virkelighed. 
SUMMARY

Word and Picture in Ethnographic Interpretation

In Moesgård museum, Denmark, there is an exhibition, Mountain People in Hindukush, based on fieldwork in the 1940s and 50s. In 1994 it was supplemented with a "photo-essay" describing the actual situation in the same community. The paper discusses the difficulties in all attempts to come close to another culture and in what way the different media of word and picture may contribute to a holistic understanding of life in a foreign society. The static exhibition with all the necessary selective operations must take into consideration both the "voices" in the culture described and the frames of understanding available to the visiting public. Oversimplifications are always a threat.

\section{LITTERATUR}

Barthes, R. 1983: Det lyse kammer.

Clement, K. 1995: Det lainte Lys.

Crawford P.I. 1992: Film as discourse: the invention of anthropological realities. In: Film as Ethnography, pp.3-7 \& 66-82. Crawford P.I.\&

D. Turton, eds.

Crawford P.I. 1992: NAFA 2. Crawford P.I.\&

J.K.Simonsen, eds.

Eco, U. 1988: Middelalderens genkomst og andre Essays.

Fentz, M. 1994: Kalasha kvindens røde perler. Jordens Folk, 2, 1994.

Fentz, M. 1996: Natural Rersources and Cosmology in Changing Kalasha Society. NIAS Reports, No 30. Nordic Insti. of Asian Studies.

Fentz, M. 1997: Kalashafolket - et billedessay. Jordens Folk, 4, 1997.

Hastrup, K. 1992: Anthropological visions: some notes on visual and textual authority. In: Film as Ethnography. Crawford P.I. \& D.Turton,eds.
Hastrup, K. 1994: Social Experience and Anthropological Knowledge. Hastrup, K. \& P. Hervik 1994 eds.

Loude J.Y. \& V. Liévre 1987: Kalash Solstice. Robertson G. S.1896/1974: The Kafirs of Hindu Kush. Karachi.

Mytte Fentz, cand.mag. i middelalder-arkaologi og etnografi. Tilknyttet Institut for Etnografi og Socialantropologi, Moesgård, Aarhus Universitet. Adr: Etnografisk Studiesamling, Moesgård Museum, DK-8270 Hojbjerg

Fax: $+45-86270708$ 